\title{
Urethral Cancer Pathologic Distant Metastasis TNM Finding v7
}

National Cancer Institute

\section{Source}

National Cancer Institute. Urethral Cancer Pathologic Distant Metastasis TNM Finding v7. NCI Thesaurus. Code C89390.

A pathologic finding about one or more characteristics of urethral cancer, following the rules of the TNM AJCC V7 classification system as they pertain to distant metastases. There is no pathologic M0 for urethral cancer. (from AJCC 7th Ed.) 